\title{
Efektivitas Pre-Lecture Quiz untuk Meningkatkan Keterampilan Berpikir Kritis Siswa
}

\author{
Nur Qomaril Fitri*, Tasviri Efkar, Sunyono \\ Program Studi Pendidikan Kimia, Universitas Lampung, Indonesia \\ Corresponding author: maril.mava1@gmail.com
}

\begin{abstract}
Effectiveness of Pre-Lecture Quiz to Improving the Critical Thinking. This research was aimed to describe the effectiveness of Pre-Lecture Quiz to improving student's critical thinking skill on Arrhenius acid-base topic. The research method used was quasi experimental with non-equivalen pretest-posttest control group design. The sample selection was done by cluster random sampling, and XI IPA 4 is obtained as experimental class and XI IPA 5 as control class. The effectiveness of Pre-Lecture Quiz was showed by the significant difference for average n-Gain of flexible thinking skill between the control and experiment class, for control class was 0.53 with middle categorize and for experiment class was 0.70 with high cateogorize. The conclusion of this research is effective Pre-Lecture Quiz and has a high effect size to improving the ability of critical thinking on Arrhenius acid-base topic.
\end{abstract}

Keywords: critical thinking, Pre-Lecture Quiz, Arrhenius acid-base

Abstrak: Efektivitas Pre-Lecture Quiz untuk Meningkatkan Keterampilan Berpikir Kritis Siswa. Penelitian ini bertujuan untuk mendeskripsikan efektivitas Pre-Lecture Quiz untuk meningkatkan keterampilan berpikir kritis siswa pada materi asam basa Arrhenius. Metode penelitian yang digunakan adalah kuasi eksperimen dengan non-equivalen pretest-posttest control group design. Pemilihan sampel dilakukan secara cluster random sampling, dan diperoleh kelas XI IPA 4 sebagai kelas eksperimen dan XI IPA 5 sebagai kelas kontrol. Efektivitas Pre-Lecture Quiz ditunjukkan oleh perbedaan rata-rata $n$-Gain keterampilan berpikir kritis yang signifikan antara kelas kelas kontrol dan eksperimen, yaitu kelas kelas kontrol sebesar 0,53 dengan kategori "sedang" dan eksperimen sebesar 0,70 dengan kategori "tinggi". Kesimpulan penelitian ini yaitu Pre-Lecture Quiz efektif dan mempunyai ukuran pengaruh yang besar untuk meningkatkan keterampilan berpikir kritis siswa pada materi asam basa Arrhenius.

Kata Kunci: keterampilan berpikir kritis, Pre-Lecture Quiz, asam basa Arrhenius 


\section{PENDAHULUAN}

Ilmu pengetahuan memiliki banyak cabang salah satu di antaranya adalah ilmu pengetahuan alam (IPA). Secara harfiah IPA dapat disebut sebagai ilmu tentang alam ini atau ilmu yang mempelajari peristiwa-peristiwa yang terjadi di alam (Nisbah, 2013). Ilmu kimia sebagai salah satu cabang IPA mempelajari tentang struktur dan komposisi materi, perubahan yang dialami materi dan fenomena-fenomena lain yang menyertai perubahan materi (Fadiawati, 2011). Ilmu kimia mencakup dua bagian yakni kimia sebagai proses dan kimia sebagai produk. Kimia sebagai proses meliputi pengamatan dan eksperimen dengan sikap ilmiah (objektif dan jujur) untuk memperoleh penemuan berupa fakta, teori, hukum, dan prinsip. Adapun kimia sebagai produk meliputi sekumpulan penemuan berupa fakta-fakta, teori, hukum dan prinsip (Permendikbud, 2014).

Karakteristik ilmu kimia yaitu pembelajaran yang memerlukan keterampilan proses sesuai dengan pembelajaran yang saat ini diterapkan di Indonesia, yaitu menggunakan Kurikulum 2013 edisi revisi. Kurikulum 2013 edisi revisi merupakan kurikulum dengan penyempurnaan standar isi, standar penilaian, dan pola pembelajaran dari kurikulum satuan tingkat pendidikan (KTSP). Pola pembelajaran harus berpusat pada siswa yang diselenggarakan secara interaktif, inspiratif, menantang, menyenangkan, serta memotivasi siswa untuk berpartisipasi secara aktif, kreatif dan juga mandiri (Permendikbud, 2013). Pada bagian standar isi, kurikulum 2013 edisi revisi memberikan pendalaman dan perluasan materi yang relevan bagi siswa yang diperkaya dengan kebutuhan siswa untuk berpikir kritis dan analitis sesuai dengan standar internasional (Widana, 2017).

Hasil tes pendidikan yang berfokus pada keterampilan siswa yang diterbitkan oleh Organization for Economic Cooperation and Development (OECD) pada tahun 2016, menunjukkan bahwa Indonesia masih menempati urutan ke 57 dari 65 negara di dunia (Nisa, 2016). Hal ini menunjukkan bahwa penerapan Kurikulum 2013 belum cukup dalam meningkatkan kualitas pendidikan di Indonesia karena dalam pelaksanaannya di lapangan belum maksimal.

Fakta tersebut juga didukung dengan hasil wawancara dengan guru kimia di salah satu SMA Negeri di Bandar Lampung yang menunjukkan bahwa keterampilan berpikir siswa di SMA Negeri tersebut khususnya keterampilan berpikir kritis masih terbilang rendah. Hal itu terlihat dari keterampilan siswa yang sangat rendah dalam: (1) memahami informasi yang kompleks; (2) teori, analisis, dan pemecahan masalah; (3) pemakaian alat, prosedur, dan pemecahan masalah serta (4) melakukan investigasi. Rendahnya keterampilan berpikir kritis siswa ini berakibat pada rendahnya prestasi belajar siswa. Dari fakta tersebut dapat diketahui bahwa siswa belum dilatihkan keterampilan berpikir kritis dengan baik, sehingga perlu adanya variasi dalam pembelajaran untuk meningkatkan keterampilan berpikir kritis siswa. Karena berpikir kritis dapat mendorong siswa untuk berpikir secara luas dan mendalam mengenai materi pelajaran.

Berpikir kritis membuat seseorang dapat mengatur, menyesuaikan, mengubah atau memperbaiki pikirannya sehingga dia dapat bertindak lebih cepat. Seseorang dikatakan berpikir kritis, apabila ia mencoba membuat berbagai pertimbangan ilmiah untuk menentukan pilihan terbaik dengan menggunakan berbagai kriteria (Liliasari, 2007).

Variasi pembelajaran yang dapat dilakukan untuk meningkatan keterampilan berpikir kritis siswa adalah dengan pemberian kuis di awal pembelajaran (Pre-Lecture Quiz) yang selanjutnya disebut PLQ (McDaniel, 2011). Tujuan dari penggunaan kuis 
untuk meningkatkan kesiapan belajar siswa dengan memberi motivasi siswa untuk membaca materi sebelum aktivitas pembelajaran. Aktivitas penugasan membaca sebelum materi pelajaran diajarkan dapat meningkatkan pemahaman siswa terhadap materi yang dipelajari (Idayu, 2017). Sehingga siswa lebih siap, aktif, dan kritis dalam mengikuti pembelajaran kimia di kelas. Penelitian Lestari (2016) memperoleh kesimpulan bahwa penerapan Pre-Lecture Quiz dapat memberikan pengaruh terhadap motivasi belajar siswa. kemudian pada penelitian Idayu (2017) juga memperoleh kesimpulan bahwa penerapan Pre-Lecture Quiz berpengaruh dalam peningkatan motivasi dan prestasi belajar siswa. Pada penelitian yang dilakukan Trisna (2017) diperoleh kesimpulan bahwa metode pemberian kuis di awal pembelajaran efektif dalam meningkatkan kesiapan dan hasil belajar siswa.

Adapun penelitian terdahulu yang dilakukan oleh Devi (2012) memperoleh kesimpulan kemampuan berpikir kritis siswa dapat ditingkatkan melalui penerapan model Pembelajaran Berbasis Masalah yang selanjutnya disebut PBM. Selain itu juga penelitian yang dilakukan Husnidar (2014) memperoleh kesimpulan peningkatan kemampuan berpikir kritis siswa yang diajarkan dengan model PBM lebih tinggi dibanding siswa yang diajarkan secara konvensional. Model PBM dimaknai sebagai model pembelajaran yang menantang siswa agar belajar untuk belajar, bekerja sama dalam kelompok untuk mencari solusi bagi masalah yang nyata. Proses pembelajaran mengarahkan agar siswa mampu menyelesaikan masalah secara sistematis, sehingga PBM merupakan model pembelajaran yang berangkat dari pemahaman siswa tentang suatu masalah, menemukan alternatif solusi atas masalah, kemudian memilih solusi yang tepat untuk digunakan dalam memecahkan masalah tersebut (Sutirman, 2013).Berdasarkan uraian di atas, maka dilakukan penelitian ini dengan judul "Efektivitas Pre-Lecture Quiz untuk Meningkatkan Keterampilan Berpikir Kritis Siswa".

\section{METODE \\ Metode Penelitian}

Metode yang digunakan dalam penelitian ini adalah kuasi eksperimen dengan desain pretest-posttest control group design (Fraenkel, 2012).

\section{Populasi dan Sampel}

Populasi dalam penelitian ini adalah siswa kelas XI IPA tahun pelajaran 2018/2019 di salah satu SMA Negeri yang berada di Bandar Lampung. Pengambilan sampel dilakukan dengan teknik cluster random sampling, didapat kelas XI IPA 5 sebagai kelas kontrol dilakukan pembelajaran tanpa menggunakan variasi PLQ dan kelas XI IPA 4 sebagai kelas eksperimen dilakukan pembelajaran dengan menggunakan variasi PLQ.

\section{Perangkat Pembelajaran dan Instrumen Penelitian}

Perangkat pembelajaran yang digunakan dalam penelitian ini yaitu silabus, RPP, dan LKS berbasis masalah.

Instrumen yang digunakan dalam penelitian ini adalah soal pre-lecture quiz, soal pretes dan postes keterampilan berpikir kritis pada materi asam basa Arrhenius. Selain itu, terdapat lembar penilaian berupa lembar penilaian aktivitas siswa selama pembelajaran. 


\section{Teknik Analisis Data}

Analisis data yang dilakukan dalam penelitian ini meliputi uji validitas dan reliabilitas instrumen, keefektifaan pre-lecture quiz, dan ukuran pengaruh. Analisis data yang telah diperoleh dihitung menggunakan software SPSS 22.0 for windows dan Microsoft Office Excel.

Uji validitas dilakukan untuk mengetahui tingkat kevalidan instrument tes yang akan digunakan dalam penelitian. Validitas soal ditentukan berdasarkan nilai $\mathrm{r}_{\text {hitung }}$ dan $r_{\text {tabel }}$. Soal dikatakan valid apabila $r_{\text {hitung }} \geq r_{\text {tabel }}$ dengan taraf signifikansi 5\%. Untuk menafsirkan koefisien korelasi, digunakan kriteria sebagai berikut.

Tabel 1.Kriteria Validitas Instrumen Tes (Arikunto, 2012)

\begin{tabular}{cc}
\hline Nilai Alpha & Interpretasi \\
\hline $0,81-1,00$ & Tinggi \\
$0,61-0,80$ & Cukup \\
$0,41-0,60$ & Agak Rendah \\
$0,21-0,40$ & Rendah \\
$0,00-0,20$ & Tidak Valid \\
\hline
\end{tabular}

Reliabilitas soal tes ditentukan menggunakan Cronbach's Alpha. Uji reliabilitas dilakukan untuk mengetahui atau menunjukkan seberapa besar kepercayaan suatu tes instrumen penelitian yang digunakan sebagai alat pengumpul data. Kriteria derajat reliabilitas $\left(\mathrm{r}_{11}\right)$ (Arikunto, 2013) ditunjukkan pada Tabel 2.

Tabel 2. Kriteria derajat reliabilitas

\begin{tabular}{cc}
\hline $\begin{array}{c}\text { Derajat } \\
\text { Reliabilitas }\end{array}$ & Interpretasi \\
\hline $0,80<\mathrm{r}_{11} \leq 1,00$ & Tinggi \\
$0,60<\mathrm{r}_{11} \leq 0,80$ & Cukup \\
$0,40<\mathrm{r}_{11} \leq 0,60$ & Agak Rendah \\
$0,20<\mathrm{r}_{11} \leq 0,40$ & Rendah \\
$0,00<\mathrm{r}_{11} \leq 0,20$ & Tidak Reliabel \\
\hline
\end{tabular}

Efektivitas pre-lecture quiz ditunjukkan dari ketercapaian dalam meningkatkan keterampilan berpikir kritis siswa yang diperoleh dari nilai pre-lecture quiz, pretes dan postes. Data nilai pretes dan postes yang diperoleh kemudian dianalisis sehingga diperoleh $n$-gain dengan rumus sebagai berikut:

$n$-Gain $=\frac{\text { nilai postes-nilai pretes }}{\text { nilai maksimum-nilai pretes }}$

Tabel 3. Kriteria n-Gain

\begin{tabular}{cc}
\hline Rata-rata n-Gain & Kriteria \\
\hline $\mathrm{g} \geq 0,7$ & Tinggi \\
$0,7>\mathrm{g} \geq 0,3$ & Sedang \\
$\mathrm{g}<0,3$ & Rendah \\
\hline
\end{tabular}

dengan kriteria rata-rata $n$-Gain (Archambault, 2008) ditunjukkan pada Tabel 3. 
Efektivitas pre-lecture quiz juga didukung dengan data aktivitas siswa selama pembelajaran yang dinilai oleh dua observer, yaitu guru mitra dan rekan peneliti. Analisis dilakukan dengan menggunakan rumus matematik menurut Sudjana (2005) berikut:

$$
\% \mathrm{Ji}=\left(\sum \mathrm{Ji} / \mathrm{N}\right) \times 100 \%
$$

Dengan \%Ji adalah persentase dari skor ideal untuk setiap aspek pengamatan pada pertemuan ke-i, $\sum \mathrm{Ji}$ adalah jumlah skor setiap aspek pengamatan yang diberikan oleh pengamat pada pertemuan ke-I, dan $\mathrm{N}$ adalah skor maksimal (skor ideal). Kemudian data yang diperoleh ditafsirkan sesuai dengan kriteria (Widoyoko, 2009) pada Tabel 4 di bawah ini.

Tabel 4. Kriteria Aktivitas Siswa

\begin{tabular}{cc}
\hline Persentase & Kriteria \\
\hline $75,1 \%-100,0 \%$ & Sangat Baik \\
$50,1 \%-75,0 \%$ & Baik \\
$25,1 \%-50,0 \%$ & Cukup Baik \\
$0,0 \%-25,0 \%$ & Kurang Baik \\
\hline
\end{tabular}

Pengujian hipotesis dalam penelitian ini dilakukan dengan uji perbedaan dua ratarata (uji-t). Sebelum dilakukan uji-t, terlebih dahulu dilakukan uji normalitas dan homogenitas untuk mengetahui apakah sampel berasal dari populasi yang berdistribusi normal dan homogen menggunakan aplikasi SPSS statistic 22.0 for Windows. Jika berdasarkan pengujian diperoleh hasil bahwa sampel berasal dari populasi yang berdistribusi normal dan homogen, maka dilakukan pengujian dengan uji statistic parametrik, dalam hal ini yaitu uji independent sampel t-test. Kriteria dari uji independent sampel $t$-test terima $\mathrm{H}_{0}$ jika nilai sig. (2-tailed) $>0,05$, yang berarti bahwa rata-rata $n$-Gain berpikir kritis siswa pada materi asam basa Arrhenius pada kelas eksperimen lebih rendah atau sama dengan rata-rata $n$-Gain berpikir kritis siswa pada materi asam basa Arrhenius pada kelas kontrol, dan terima $\mathrm{H}_{1}$ apabila nilai sig. (2tailed $)<0,05$, yang berarti bahwa rata-rata $n$-Gain berpikir kritis siswa pada materi asam basa Arrhenius di kelas eksperimen lebih tinggi dari rata-rata $n$-Gain berpikir kritis siswa pada materi asam basa Arrhenius di kelas kontrol.

Berdasarkan nilai t hitung yang diperoleh dari uji independent sampel t-test, kemudian dilakukan perhitungan untuk menentukan ukuran pengaruh (effect size) prelecture quiz menurut Jahjouh (2014) dengan rumus:

$$
\mu^{2}=\frac{\mathrm{t}^{2}}{\mathrm{t}^{2}+d f}
$$

dengan $\mu$ adalah effect size, $\mathrm{t}$ adalah t hitung dari uji-t, dan df adalah derajat kebebasan. Kriteria menurut Dincer (2015) ditunjukkan pada Tabel 5.

Tabel 5. Kriteria Effect Size

\begin{tabular}{cc}
\hline Effect Size & Kriteria \\
\hline $\boldsymbol{\mu} \leq 0,15$ & Efek diabaikan \\
$0,15<\boldsymbol{\mu} \leq 0,40$ & Efek kecil \\
$0,40<\boldsymbol{\mu} \leq 0,75$ & Efek sedang \\
\hline
\end{tabular}




\begin{tabular}{cc}
\hline $0,75<\boldsymbol{\mu} \leq 1,10$ & Efek besar \\
$\boldsymbol{\mu}>1,10$ & Efek sangat besar \\
\hline
\end{tabular}

\section{HASIL DAN PEMBAHASAN Validitas dan Reliabilitas}

Berdasarkan data hasil validitas dan reliabilitas instrumen tes yang diujicobakan kepada 20 siswa diperoleh hasil yang ditunjukkan pada Tabel 6. Pada Tabel 6 menunjukkan bahwa soal tes keterampilan berpikir kritis yang berjumlah 5 butir untuk teori asam dan basa Arrhenius adalah valid karena memiliki nilai $\mathbf{r}_{\text {hitung }}$ yang lebih besar dari $r_{\text {tabel }}\left(r_{\text {hitung }}>r_{\text {tabel }}\right)$, sehingga dapat digunakan sebagai instrumen pengukuran keterampilan berpikir kritis siswa.

Tabel 6. Nilai Koefisien Validitas

\begin{tabular}{cccc}
\hline $\begin{array}{c}\text { Butir } \\
\text { Soal }\end{array}$ & $\mathrm{r}_{\text {Hitung }}$ & $\mathrm{R}_{\text {Tabel }}$ & Keterangan \\
\hline 1 & 0,842 & 0,444 & Valid \\
2 & 0,820 & 0,444 & Valid \\
3 & 0,740 & 0,444 & Valid \\
4 & 0,640 & 0,444 & Valid \\
5 & 0,726 & 0,444 & Valid \\
\hline
\end{tabular}

Hasil dari uji reabilitas soal pretes/postes kemampuan berpikir kritis siswa adalah sebesar 0,792. Menurut Guilford, kriteria reliabilitas soal tes kemampuan berpikir kritis siswa adalah tinggi yaitu $0,60<\mathrm{r}_{11} \leq 0,80$ sehingga dapat digunakan sebagai instrumen pengukuran kemampuan berpikir kritis siswa.

\section{Efektivitas Pre-Lecture Quiz}

Pre-lecture quiz diberikan pada setiap pertemuan di awal pembelajaran. Pada hari berbeda, sebelum pembelajaran dilaksanakan peneliti telah terlebih dahulu memberikan penjelasan kepada siswa bahwa akan dilaksanakan pembelajaran dengan menggunakan variasi pre-lecture quiz pada kelas eksperimen, yaitu pemberian kuis di awal pembelajaran yang bertujuan untuk meningkatkan pembelajaran, memberi motivasi siswa untuk membaca materi sebelum pembelajaran. Aktivitas penugasan membaca sebelum materi pelajaran diajarkan dapat meningkatkan pemahaman siswa terhadap materi yang dipelajari (Idayu, 2017). Dalam pembelajaran, peneliti membagi siswa menjadi kelompok-kelompok kecil. Setiap kelompok diberikan LKS berbasis masalah. Pada penutup pembelajaran, peneliti selalu mengingatkan siswa bahwa setiap awal pembelajaran akan dilaksanakan kuis berupa materi pembelajaran yang akan didiskusikan pada hari tersebut. 


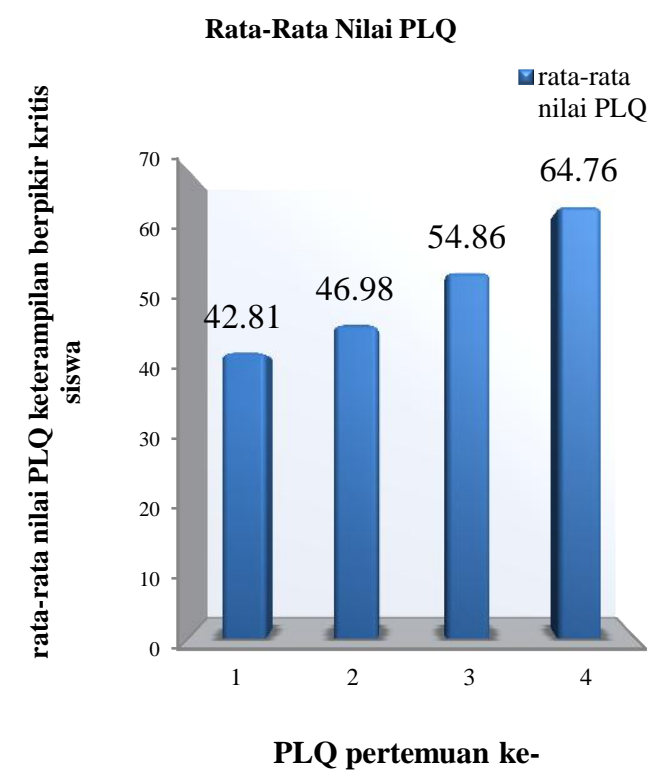

Gambar 1. Rata-rata Nilai PLQ Siswa Kelas Eksperimen

Diperoleh data berupa nilai pre-lecture quiz (PLQ) keterampilan berpikir kritis siswa kelas experimen pada teori asam dan basa Arrhenius. Rata-rata nilai PLQ yang diperoleh siswa pada pertemuan pertama adalah 42,81. Kemudian pada pertemuan ke dua rata-rata nilai PLQ siswa meningkat menjadi 46,98. Peningkatan rata-rata nilai PLQ siswa ini terus terjadi hingga pertemuan terakhir yaitu 54,86 untuk pertemuan tiga dan 64,76 untuk pertemuan ke empat. Rata-rata nilai PLQ keterampilan berpikir kritis siswa pertemuan satu hingga pertemuan empat disajikan pada Gambar 1.

Berdasarkan nilai PLQ dari masing-masing siswa dari pertemuan pertama hingga pertemuan ke empat diketahui bahwa ada siswa yang mengalami peningkatan, penurunan, maupun tidak mengalami perubahan nilai pada setiap kuisnya. Dari kuis pertama ke kuis dua jumlah siswa yang mengalami peningkatan nilai adalah 23 siswa, sedangkan yang tidak mengalami peningkatan maupun penurunan nilai adalah 8 siswa, dan yang mengalami penurunan nilai ada 5 siswa. Adapun dari kuis dua ke kuis tiga jumlah siswa yang mengalami peningkatan nilai adalah 29 siswa, sedangkan yang tidak mengalami peningkatan maupun penurunan nilai adalah 5 siswa, dan yang mengalami penurunan nilai ada 2 siswa. Terakhir dari kuis tiga ke kuis empat jumlah siswa yang mengalami peningkatan nilai adalah 33 siswa, sedangkan yang tidak mengalami peningkatan maupun penurunan nilai adalah 2 siswa, dan yang mengalami penurunan nilai ada 1 siswa. 


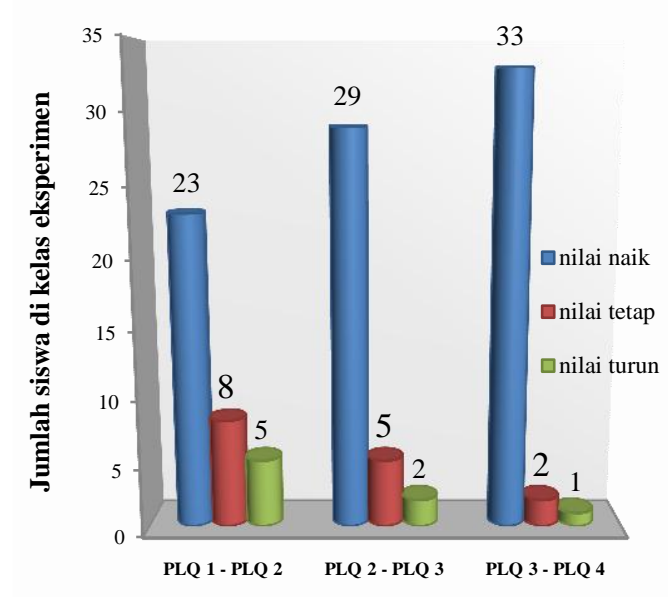

Gambar 2. Jumlah Siswa Mengalami Nilai PLQ Naik, Tetap, dan Turun dari Pertemuan ke Dua Hingga ke Empat

Dari data ini diketahui jumlah siswa yang mengalami peningkatan nilai kuis terus bertambah, sedangkan jumlah siswa yang tidak mengalami peningkatan maupun penurunan nilai kuis, dan jumlah siswa yang mengalami penurunan nilai kuis terus berkurang.

Hal ini menunjukkan bahwa PLQ efektif dalam meningkatkan keterampilan berpikir kritis siswa pada materi asam basa Arrhenius yang bersesuaian dengan pendapat Slameto (2010) bahwa penerapan Pre-Lecture Quiz (PLQ) dapat membuat siswa lebih siap untuk belajar kimia sehingga membuahkan hasil belajar yang lebih baik. Selain itu, sejalan dengan penelitian Idayu (2017) bahwa terjadi peningkatan nilai PLQ siswa pada materi asam basa.

\section{Keterampilan Berpikir Kritis}

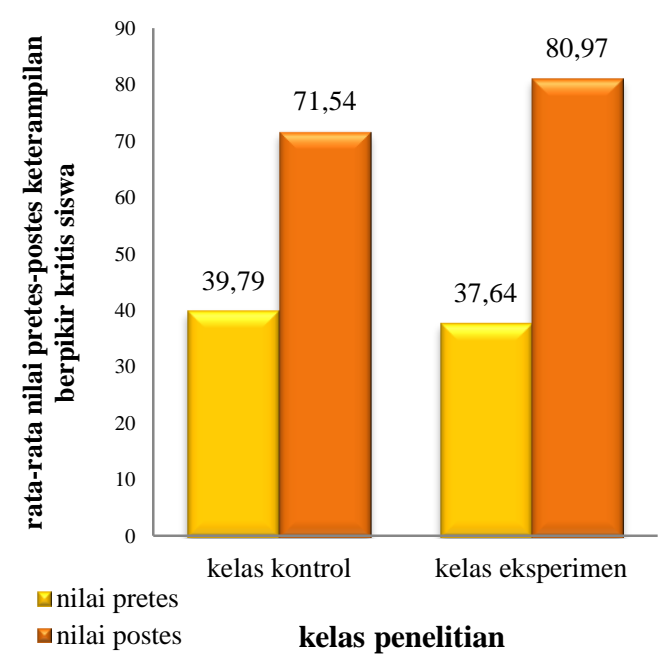

Gambar 3. Rata-rata nilai pretes dan postes siswa

Efektivitas PLQ diukur dari ketercapaian dalam meningkatkan keterampilan berpikir kritis siswa yang dapat dilihat berdasarkan perhitungan secara statistik nilai 
pretes dan postes siswa. Rata-rata nilai pretes dan postes keterampilan berpikir kritis siswa disajikan pada Gambar 3 di atas.

Hasil rata-rata pretes untuk kelas kontrol dan kelas eksperimen tidak jauh berbeda, yaitu 39,80 dan 37,60. Hasil rata-rata postes untuk kelas kontrol dan kelas eksperimen yaitu 71,50 dan 81,00. Hal ini menunjukkan bahwa selisih rata-rata nilai pretes-postes untuk kelas eksperimen lebih tinggi dibandingkan dengan kelas kontrol. Adapun peningkatan keterampilan berpikir kritis siswa pada kedua kelas dideskripsikan oleh rata-rata $n$-Gain yang ditunjukkan oleh Gambar 4 berikut.

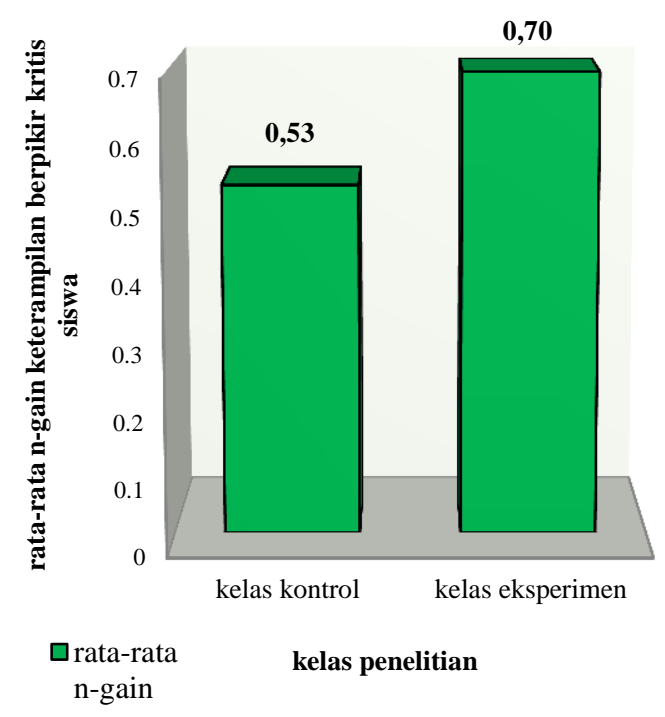

Gambar 4. Rata-rata nilai n-Gain

Berdasarkan Gambar 4 diketahui rata-rata nilai $n$-Gain kelas kontrol yaitu 0,53 yang memiliki kategori sedang dan rata-rata nilai $n$-Gain kelas eksperimen yaitu 0,70 yang memiliki kategori sedang. Hasil rata-rata $n$-Gain pada kelas kontrol dan eksperimen menunjukkan kriteria yang sama yaitu "sedang" namun dengan nilai $n$-Gain kelas eksperimen lebih tinggi dari kelas kontrol menunjukkan bahwa PLQ pada pembelajaran berbasis masalah efektif dalam meningkatkan keterampilan berpikir kritis siswa pada materi asam basa Arrhenius.

\section{Aktivitas Siswa selama Pembelajaran Mengunakan Variasi Pre-Lecture Quiz (PLQ)}

Pengamatan terhadap aktivitas siswa selama pembelajaran dengan menggunakan model PBM dinilai oleh dua pengamat yaitu guru mitra dan rekan penelitian.

Hasil pengamatan menunjukkan bahwa aktivitas siswa selama pembelajaran dengan menggunakan model pembelajaran berbasis masalah dari pertemuan 1 sampai 4 mengalami peningkatan. Rata-rata persentase aktivitas siswa selama pembelajaran di kelas kontrol yaitu $75,25 \%$ dengan kriteria "sangat tinggi", sedangkan rata-rata persentase aktivitas siswa selama pembelajaran di kelas eksperimen yaitu 78,88\% dengan kriteria "sangat tinggi". 


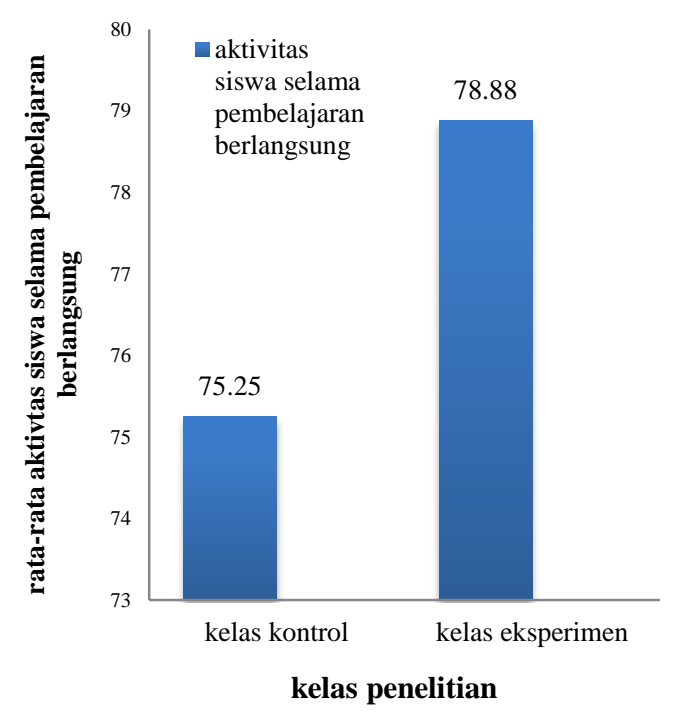

Gambar 5. Rata-rata Aktivitas Siswa Selama Pembelajaran Berlangsung

Rata-rata persentase aktivitas siswa selama pembelajaran di kelas eksperimen lebih tinggi dibanding kelas kontrol. Hal ini menunjukkan aktivitas siswa selama pembelajaran menggunakan model PBM dengan variasi PLQ efektif dalam meningkatkan keterampilan berpikir kritis siswa khususnya pada materi asam basa Arrhenius. Aktivitas siswa selama pembelajaran efektif dalam meningkatkan keterampilan berpikir kritis siswa karena dalam pembelajaran PBM menggunakan variasi PLQ siswa sudah siap dalam menerima pembelajaran, sehingga siswa lebih antusias, banyak bertanya, kritis, ulet, dan disiplin.

Rata-rata aktivitas siswa selama pembelajaran dengan variasi PLQ pada pada pembelajaran berbasis masalah memiliki kriteria "sangat tinggi". Hal ini berarti PLQ pada pembelajaran berbasis masalah efektif untuk meningkatkan kesiapan belajar siswa yang berefek pada peningkatan keterampilan berpikir kritis siswa pada materi asam basa Arrhenius. Hal tersebut didukung oleh penelitian Trisna (2017) bahwa metode pemberian kuis di awal pembelajaran efektif dalam meningkatkan kesiapan dan hasil belajar siswa. Juga penelitian yang dilakukan oleh Devi (2012) yang menyimpulkan kemampuan berpikir kritis peserta didik dapat ditingkatkan melalui penerapan model Problem Based Learning.

\section{Uji Hipotesis}

Uji normalitas digunakan untuk mengetahui apakah dua kelompok sampel berasal dari populasi berdistribusi normal atau tidak (Arikunto, 2006). Uji normalitas dilakukan dengan uji Kolmogorov-Smirnov Test dengan taraf signifikansi $(\alpha) 0,05$. Berikut ini adalah hasil uji normalitas nilai pretes, postes, dan $n$-Gain keterampilan berpikir kritis siswa pada kelas kontrol dan kelas eksperimen.

Hasil uji normalitas dan homogenitas berpikir kreatif siswa pada kelas eksperimen dan kelas kontrol dapat dilihat pada tabel berikut.

Tabel 7. Hasil Uji Normalitas

\begin{tabular}{c} 
Kelas $\quad \frac{n-G a i n}{}$ \\
\cline { 2 - 2 }
\end{tabular}




\begin{tabular}{ccc}
\hline Kontrol & 0,200 & Normal \\
Eksperimen & 0,200 & Normal \\
\hline
\end{tabular}

Berdasarkan Tabel 7, terlihat bahwa nilai sig. yang diperoleh pada uji normalitas keterampilan berpikir kritis siswa lebih besar dari 0,05, artinya kedua sampel berasal dari populasi yang berdistribusi normal.

Uji homogenitas merupakan uji prasyarat yang bertujuan untuk mengetahui apakah variansi populasi bersifat seragam atau tidak berdasarkan data sampel yang diperoleh (Arikunto, 2013). Uji homogenitas diuji dengan menggunakan uji Levene Statistic dengan taraf signifikansi $(\alpha) 0,05$.

Tabel 8. Hasil Uji Homogenitas

\begin{tabular}{ccc}
\hline \multirow{2}{*}{$\begin{array}{c}\text { Aspek } \\
\text { yang } \\
\text { dinilai }\end{array}$} & \multicolumn{2}{c}{ Keterampilan Berpikir } \\
\cline { 2 - 3 } & $\begin{array}{c}\text { Nilai } \\
\text { sig }\end{array}$ & Kriteria Uji \\
\hline Pretes & 0,147 & Homogen \\
Postes & 0,334 & Homogen \\
$n$-Gain & 0,415 & Homogen \\
\hline
\end{tabular}

Berdasarkan tabel 8, nilai sig lebih dari 0,05 untuk data pretes, postes, dan $n$-Gain yang berarti terima $\mathrm{H}_{0}$. Berdasarkan kriteria uji maka terima $\mathrm{H}_{0}$ yaitu data pretes, postes, dan $n$-Gain pada kelas kontrol dan kelas eksperimen mempunyai nilai varians yang homogen.

\section{Uji Perbedaan Dua Rata-Rata (Uji-t)}

Uji hipotesis yang dilakukan oleh peneliti adalah uji perbedaan dua rata-rata (Independent Sample t-Test). Berdasarkan hasil uji normalitas dan uji homogenitas yang telah dilakukan, diperoleh data $n$-Gain pada kelas kontrol dan eksperimen berdistribusi normal dan mempunyai varians homogen sehingga dapat dilanjutkan dengan uji $\mathrm{t}$ menggunakan uji Independent Sample t-Test. Hasil uji t disajikan pada tabel di bawah ini.

Tabel 9. Hasil Uji Perbedaan Dua Rata-Rata

\begin{tabular}{ccc}
\hline Kelas & $\begin{array}{c}\text { Rata-Rata } \\
n \text {-Gain }\end{array}$ & $\begin{array}{c}\text { sig. (2- } \\
\text { tailed })\end{array}$ \\
\hline Kontrol & 0,53 & 0,000 \\
Eksperimen & 0,70 & 0,000 \\
\hline
\end{tabular}

Hasil uji Independent Sample t-Test menunjukkan bahwa nilai signifikansi yang diperoleh sebesar 0,000. Berdasarkan kriteria uji terima $\mathrm{H}_{1}$ jika nilai sig. $<0,05$ dan sebaliknya (Sudjana, 2005), maka hasil uji terima $\mathrm{H}_{1}$, sehingga dikatakan bahwa ratarata $n$-Gain berpikir kritis siswa pada teori asam basa Arrhenius pada kelas eksperimen lebih tinggi dari rata-rata $n$-Gain berpikir kritis siswa pada teori asam basa Arrhenius pada kelas kontrol. 
Hal ini menunjukkan bahwa PLQ dapat mempengaruhi perbedaan nilai postes pada kelas kontrol dan kelas eksperimen. Hal ini dikarenakan pada kelas eksperimen, siswa lebih siap dalam menerima pembelajaran karena siswa sudah mempunyai pengetahuan awal dengan mempersiapkan diri untuk kuis, sedangkan pada kelas kontrol, siswa belum siap dalam menerima pembelajaran karena tidak diberikan kuis di awal pembelajaran sehingga tidak mendorong siswa untuk mempersiapkan diri melaksanakan pembelajaran.

\section{Ukuran Pengaruh (Effect Size)}

Peningkatan keterampilan berpikir kreatif siswa diuji dengan menggunakan uji effect size. Nilai effect size yang diperoleh pada kelas kontrol 0,86 dengan kriteria "besar" dan pada kelas esperimen 0,88 dengan kriteria "besar". Nilai effect size yang diperoleh pada kelas eksperimen lebih besar dibanding kelas kontrol. Hasil ini juga memberikan informasi bahwa sebesar $86 \%$ peningkatan keterampilan berpikir kritis siswa pada kelas eksperimen dipengaruhi oleh variasi PLQ dan model PBM, sedangkan 14\% dipengaruhi oleh faktor lain yang diabaikan. Hal ini menunjukkan bahwa PLQ mempunyai pengaruh "besar" dalam meningkatkan keterampilan berpikir kritis siswa pada teori asam basa Arrhenius. Relevan dengan kriteria Dincer (2015) yang menyatakan jika hasil uji effect size berada pada rentang $0,75<\mu \leq 1,10$, maka dikategorikan sebagai "efek besar".

Tabel 10. Hasil Uji Effect Size

\begin{tabular}{ccc}
\hline Kelas & Effect Size & Kriteria \\
\hline Kontrol & 0,86 & Sedang \\
Eksperimen & 0,88 & Besar \\
\hline
\end{tabular}

\section{KESIMPULAN}

Berdasarkan hasil analisis data dan pembahasan mengenai efektivitas pre-lecture quiz pada pembelajaran berbasis masalah untuk meningkatkan keterampilan berpikir kritis siswa pada teori asam basa Arrhenius, maka diperoleh kesimpulan bahwa penerapan pre-lecture quiz pada pembelajaran berbasis masalah efektif dalam meningkatkan keterampilan berpikir kritis siswa pada teori asam basa Arrhenius. Hal ini dibuktikan dengan hasil rata-rata nilai pre-lecture quiz siswa kelas eksperimen terus mengalami peningkatan dari kuis pertama hingga kuis ke empat, hasil rata-rata aktivitas siswa pada pembelajaran pre-lecture quiz pada kelas eksperimen memiliki kriteria "sangat tinggi", dan rata-rata $n$-Gain pada kelas eksperimen lebih tinggi dibanding kelas kontrol. Pre-lecture quiz pada pembelajaran berbasis masalah mempunyai pengaruh yang "besar" dalam meningkatkan keterampilan berpikir kritis siswa pada materi asam basa Arrhenius.

\section{REFERENSI}

Archambault, J. 2008. The Effect of Developing Kinematics Concepts Graphically Prior to Introducing Algebraic Problem Solving Techniques. Action Research Required for The Master of Natural Science Degree with Concentration kin Physics; Arizona State University.

Arikunto. 2012. Prosedur Penelitian suatu Pendekatan Praktik. Jakarta: Rineka Cipta. 
Arikunto. 2013. Prosedur Penelitian suatu Pendekatan Praktik. Jakarta: Rineka Cipta.

Danial, M. 2013. Perbandingan Hasil Belajar Siswa yang Diberi Tugas Rumah dan Kuis pada Model Pembelajaran Langsung (Studi pada Materi Pokok Reaksi Redoks). Jurnal Chemical, 14(1): 66-73.

Devi. 2012. Penerapan Model Problem Based Learning (PBL) untuk Meningkatkan Kemampuan Berpikir Kritis Peserta Didik Pada Pembelajaran IPA Kelas VIII SMP Negeri 5 Sleman. Jurnal Pendidikan Ilmu Pengetahuan Alam, 1(2).

Dincer, S. 2015. Effect of Computer Assisted Learning on Students' Achievement in Turkey: a Meta-Analysis. Journal of Turkish Science Education, 12(1): 99-118.

Fadiawati, N. 2011. Perkembangan Konsepsi Pembelajaran Tentang Struktur Atom dari SMA Hingga Perguruan Tinggi. (Disertasi) Bandung: SPs-UPI.

Fraenkel, J. R., Wallen N. E., dan Hyun H. H. 2012. How to Design and Evaluate Research in Education (Eight Edition). New York: McGrow-Hill Companies.

Husnidar, I. M., Rizal, S . 2014. Penerapan Model Pembelajaran Berbasis Masalah untuk Meningkatkan Kemampuan Berpikir Kritis dan Disposisi Matematika Siswa. Jurnal Didaktik Matematika, 1(1).

Idayu, G. 2017. Pengaruh Penerapan Pre-Lecture Quiz (PLQ) pada Pembelajaran Kimia terhadap Motivasi dan Prestasi Belajar Siswa SMA N 1 Kalasan Kelas XI Tahun Ajaran 2015/2016. Journal Student UNY, 5(4): 6-7.

Jahjouh, Y. M. A. 2014. The effectiveness of Blended E-Learning Forum In Planning For Science Instruction. Journal Of Turkish Science Education, 11(4).

Lestari, F. 2016. Pengaruh Penerapan Pre-Lecture Quiz (PLQ) pada Pembelajaran Kimia Terhadap Motivasi dan Prestasi Belajar Siswa. Journal Student UNY, 5(4): 6-7.

Liliasari. 2007. Model-Model Pembelajaran Berbasis Teknologi Informasi Untuk Mengembangkan Keterampilan Generic Sains dan Berpikir Tingkat Pelajar. Bandung: UPI.

Nisa. 2016. Peringkat Pendidikan Indonesia. Diakses di http://edu post.id/internasional/pendidikan-indonesia-berada-di-peringkat-ke-57-dunia-versioecd/ pada tanggal 17 November 2018.

Nisbah F. 2013. Hakikat IPA. Semarang: Aneka Ilmu.

Permendikbud. 2013. Pembelajaran pada Pendidikan Dasar dan Pendidikan Menengah. Jakarta: Kemendikbud.

Permendikbud. 2014. Pembelajaran pada Pendidikan Dasar dan Pendidikan Menengah. Jakarta: Kemendikbud.

Slameto. 2015. Belajar dan Faktor-Faktor yang Mempengaruhinya. Jakarta: Rineka Cipta.

Sudjana. 2005. Metode Statistika. Bandung: Tarsito.

Sutirman. 2013. Media \& Model-model Pembelajaran Inovatif. Yogyakarta: Graha Ilmu.

Trisna, I. K. 2017. Pemberian Kuis di Awal Pembelajaran untuk Meningkatkan Kesiapan dan Hasil Belajar Siswa Kelas X MIPA. Jurnal Pendidikan Kimia Indonesia, 1(2).

Widana, I.W. 2017. Modul Penyusunan Soal HOTS. Direktorat Jenderal Pendidikan Jakarta: Dasar dan Menengah.

Widoyoko, E. P. 2009. Evaluasi Program Pembelajaran. Yogyakarta: Pustaka Pelajar. 